\title{
Akses Masyarakat Adat Terhadap Peluang-peluang Pembangunan Kehutanan di Kabupaten Manokwari
}

Oleh Max J. Tokede, Dede Wiliam, Siân McGrath, dan Yosias Gandhi

\section{Pendahuluan}

Era desentralisasi di Papua berawal pada tahun 2000 ketika mereka memperoleh Otonomi Khusus (Otsus). Sejak saat itu paradigma baru dalam pengelolaan hutan di Papua telah beralih ke pengelolaan hutan berbasis masyarakat. Kebijakan desentralisasi dianggap lebih sesuai untuk menjembatani keinginan dan kepentingan antara masyarakat hukum adat (lokal) dengan kepentingan pembangunan sektor kehutanan secara luas. Perubahan ini memberikan kesempatan pada masyarakat setempat sebagai pemilik hak ulayat ${ }^{1}$ untuk berperan aktif dalam pengelolaan hutan seperti yang diamanatkan oleh Undang-undang No. 21/20012 tentang Otonomi Khusus untuk Provinsi Papua, yang juga dijelaskan dalam Pasal 67 ayat 1 UU No. 41/1999 tentang Kehutanan.

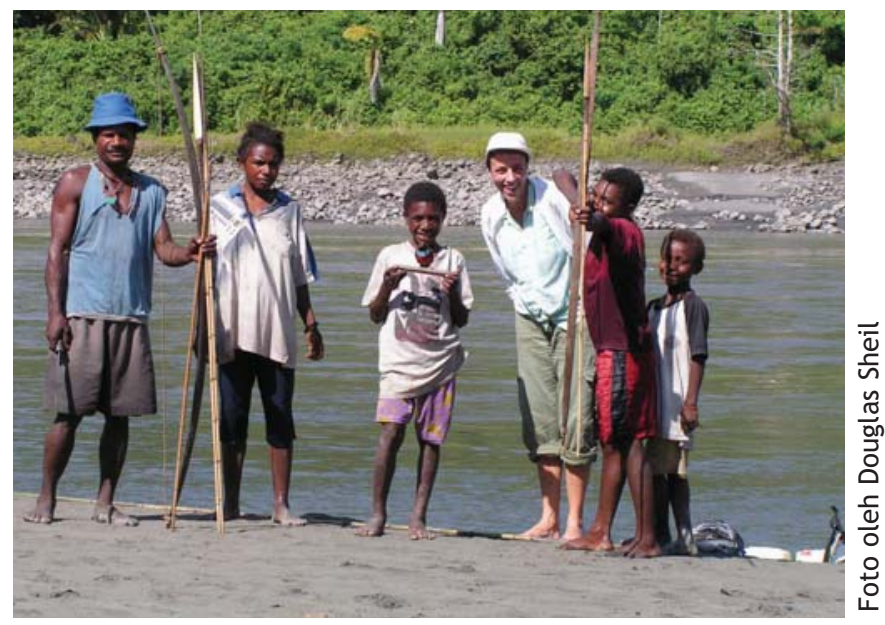

Masih dalam kerangka desentralisasi, pada bulan Mei 1999 Menteri Kehutanan mengeluarkan dua keputusan yang mengatur hak-hak masyarakat lokal untuk memperoleh manfaat dari hasil hutan ${ }^{3}$. Keputusan Menteri (Kepmen) ini memberikan kesempatan pada masyarakat lokal untuk menggunakan haknya dalam mengelola dan mendapatkan hasil hutan serta memberikan wewenang pada pemerintah kabupaten dalam pengelolaan sumberdaya hutan yang ada di daerahnya, baik itu hutan adat atau hutan negara. Berdasarkan kebijakan tersebut, kelompok-kelompok masyarakat yang telah memperoleh pengakuan resmi seperti koperasi masyarakat atau kelompok lainnya, dan/atau perusahaan swasta dapat memperoleh hak pengelolaan hutan skala kecil dalam bentuk HPHH (Hak Pemungutan Hasil Hutan) atau HPHH-MA (Hak Pemungutan Hasil Hutan untuk Masyarakat Adat). Kepmen pertama yaitu No. 310/kpts-II/1999 yang mengatur mengenai HPHH-yang pada saat sekarang sudah tidak berlaku lagi ${ }^{4}-$ memberikan peluang pada masyarakat lokal untuk dapat memperoleh manfaat dari hutan, melalui pemungutan hasil hutan dari izin konsesi seluas 100 ha selama satu tahun. Kebanyakan pemerintah kabupaten di seluruh Indonesia menjadikan ketentuan ini sebagai acuan untuk menetapkan kebijakan mengenai pemanfaatan hasil hutan oleh masyarakat di daerahnya masing-masing.

Sementara itu, Kepmen yang kedua mengenai (HPHH-MA) mengatur kegiatan-kegiatan yang bersifat non komersial. Aturan ini masih berlaku dan memungkinkan masyarakat untuk memanfaatkan hasil hutan baik di dalam maupun di luar hutan negara dalam jangka waktu yang tak terbatas. Hal tersebut di jelaskan dalam aturan pelaksanaannya yang ditetapkan dalam Keputusan Dirjen ${ }^{5}$. Selama desentralisasi berlangsung, baru Provinsi Papua (yang pada saat ini telah terbagi menjadi dua provinsi yaitu Irian Jaya Barat dan Papua) yang telah mengimplementasikan ketentuan pelaksanaan hak-hak pemungutan hasil hutan oleh masyarakat adat (HPHH-MA) tersebut.

Kebijakan dari Pemerintah Pusat yang mengatur hak-hak pemungutan hasil hutan oleh masyarakat adat cenderung kontradiktif satu sama lain. Sebagai contoh, Kepmen yang menetapkan bahwa Bupati diberi kewenangan untuk mengeluarkan perizinan untuk pengelolaan hutan oleh masyarakat, sementara keputusan 
Tabel 1. Analisis kebijakan sistem alokasi perizinan di Kabupaten Manokwari

\begin{tabular}{|c|c|c|c|}
\hline Komponen & Kebijakan Pemerintah Pusat & Kebijakan Pemerintah Provinsi & $\begin{array}{l}\text { Kebijakan Pemerintah } \\
\text { Kabupaten }\end{array}$ \\
\hline Dasar Acuan & $\begin{array}{l}\text { SK Menteri No. 317/kpts-II/1999 } \\
\text { tentang Pedoman Pemberian Hak } \\
\text { Pemungutan Hasil Hutan Masyarakat } \\
\text { Hukum Adat pada Areal Hutan } \\
\text { Produksi; petunjuk pelaksanaannya } \\
\text { dijabarkan dalam SK Dirjen } \\
\text { PHP No.199/kpts/VI-SET/1999. }\end{array}$ & $\begin{array}{l}\text { SK Gubernur No. } \\
522.2 / 3386 / S E T / 2002 \text { tentang } \\
\text { Penyusunan IPK-MA; petunjuk } \\
\text { pelaksanaannya dijabarkan } \\
\text { dalam SK Kepala Dinas } \\
\text { Kehutanan Papua) No. } \\
522.1 / 1648 / 2002 \text {. }\end{array}$ & $\begin{array}{l}\text { SK Bupati Manokwari } \\
\text { No. } 274 / 2004 \text { tentang Perizinan } \\
\text { untuk Pengelolaan Hutan Adat } \\
\text { dalam Hutan Negara di areal } \\
\text { hutan produksi (IHPHA). }\end{array}$ \\
\hline $\begin{array}{l}\text { Hal-hal yang } \\
\text { diatur dalam } \\
\text { Pemanfaatan } \\
\text { hutan }\end{array}$ & $\begin{array}{l}\text { Ambiguitas hukum: SK Menteri } \\
\text { menetapkan hanya tujuan-tujuan } \\
\text { pemungutan secara non komersial } \\
\text { yang diperbolehkan, tetapi aturan } \\
\text { pelaksanaannya juga mengatur } \\
\text { pemanfaatan secara komersial. }\end{array}$ & $\begin{array}{l}\text { Pemungutan hasil hutan untuk } \\
\text { tujuan-tujuan komersial. }\end{array}$ & $\begin{array}{l}\text { Pemungutan hasil hutan untuk } \\
\text { tujuan-tujuan komersial. }\end{array}$ \\
\hline $\begin{array}{l}\text { Yang berhak } \\
\text { memiliki izin }\end{array}$ & $\begin{array}{l}\text { Lembaga atau organisasi masyarakat } \\
\text { adat yang telah memperoleh } \\
\text { pengakuan resmi melalui SK Bupati } \\
\text { berhak memiliki izin pemungutan } \\
\text { hasil hutan. }\end{array}$ & $\begin{array}{l}\text { Kelompok atau organisasi } \\
\text { masyarakat yang berbadan } \\
\text { hukum, mitra kerja, pemilik } \\
\text { izin HPH atau IPK, dan koperasi } \\
\text { peran serta masyarakat } \\
\text { (Kopermas). }\end{array}$ & $\begin{array}{l}\text { Keputusan ini menegaskan } \\
\text { bahwa izin hanya diberikan pada } \\
\text { koperasi peran serta masyarakat } \\
\text { (Kopermas) }\end{array}$ \\
\hline $\begin{array}{l}\text { Kewenangan } \\
\text { Pemerintah } \\
\text { Daerah }\end{array}$ & $\begin{array}{l}\text { Ambiguitas hukum: SK Menteri } \\
\text { memberikan kewenangan pada } \\
\text { Bupati untuk mengeluarkan } \\
\text { perizinan, tetapi SK Dirjen } \\
\text { menetapkan bahwa Kepala Dinas } \\
\text { Kehutanan, dengan persetujuan } \\
\text { Gubernur, adalah pejabat berwenang } \\
\text { yang mengeluarkan perijinan. }\end{array}$ & $\begin{array}{l}\text { Kepala Dinas Kehutanan Provinsi } \\
\text { berwenang untuk mengeluarkan } \\
\text { perizinan dengan rekomendasi } \\
\text { dari Dinas Kehutanan } \\
\text { Kabupaten. }\end{array}$ & $\begin{array}{l}\text { Bupati berwenang mengeluarkan } \\
\text { perizinan berdasarkan } \\
\text { rekomendasi teknis dari } \\
\text { Dinas Kehutanan Kabupaten . } \\
\text { Tanggung jawab pengawasan } \\
\text { dan pelaksanaan ada pada Dinas } \\
\text { Kehutanan Kabupaten. }\end{array}$ \\
\hline $\begin{array}{l}\text { Petunjuk } \\
\text { Pelaksanaan } \\
\text { dan Fungsi } \\
\text { Pengawasan }\end{array}$ & $\begin{array}{l}\text { Tanggung jawab pengawasan/ } \\
\text { pelaksanaan ada pada Dinas } \\
\text { Kehutanan Kabupaten; tetapi } \\
\text { Dinas Kehutanan Provinsi memiliki } \\
\text { tanggung jawab atas proses } \\
\text { permohonan dan pemberian izin. } \\
\text { Keputusan ini tidak memberikan } \\
\text { petunjuk pelaksanaan teknis. }\end{array}$ & $\begin{array}{l}\text { Dinas Kehutanan Kabupaten } \\
\text { bertanggung jawab bagi } \\
\text { pengawasan dan pelaksanaan } \\
\text { perizinan IPK-MA. Petunjuk } \\
\text { pelaksanaan teknis ada, tetapi } \\
\text { tidak dijelaskan secara rinci. }\end{array}$ & $\begin{array}{l}\text { Keputusan ini mengatur secara } \\
\text { lebih rinci dan jelas mengenai } \\
\text { Petunjuk pelaksanaan teknis di } \\
\text { lapangan. }\end{array}$ \\
\hline Jangka waktu & $\begin{array}{l}\text { Ambiguitas hukum: SK Menteri } \\
\text { tidak menetapkan jangka waktu } \\
\text { tertentu untuk pemungutan hasil } \\
\text { hutan (untuk tujuan non komersial } \\
\text { saja), tetapi SK Dirjen sebagai } \\
\text { aturan pelaksanaannya menetapkan } \\
\text { jangka waktu tak terbatas, yaitu } \\
\text { "sepanjang masyarakat masih } \\
\text { ada” (termasuk untuk pemungutan } \\
\text { komersial). }\end{array}$ & $\begin{array}{l}\text { Perizinan berlaku selama satu } \\
\text { tahun dengan kemungkinan } \\
\text { perpanjangan. }\end{array}$ & $\begin{array}{l}\text { Perizinan berlaku selama } 20 \\
\text { tahun. }\end{array}$ \\
\hline Luas wilayah & Tidak dijelaskan. & $250-1.000$ ha. & 2.000 ha. \\
\hline Daerah hutan & $\begin{array}{l}\text { Kawasan hutan negara (areal hutan } \\
\text { produksi dan konversi). }\end{array}$ & $\begin{array}{l}\text { Kawasan hutan negara yang } \\
\text { diperuntukkan sebagai areal } \\
\text { hutan produksi, baik yang sudah } \\
\text { ada atau belum terdapat HPH di } \\
\text { dalamnya, dan dalam wilayah } \\
\text { APL (Areal Penggunaan Lain). }\end{array}$ & $\begin{array}{l}\text { Kawasan hutan negara yang } \\
\text { diperuntukkan sebagai areal } \\
\text { hutan produksi, baik yang sudah } \\
\text { ada atau belum terdapat HPH di } \\
\text { dalamnya, dan dalam wilayah } \\
\text { "hutan adat” (daerah di luar } \\
\text { kawasan hutan negara). }\end{array}$ \\
\hline $\begin{array}{l}\text { Upaya } \\
\text { Penyelamatan } \\
\text { Lingkungan }\end{array}$ & $\begin{array}{l}\text { Diharuskan menanam kembali } \\
\text { sejumlah pohon yang ditebang. }\end{array}$ & $\begin{array}{l}\text { Diharuskan menanam kembali } \\
\text { sejumlah pohon yang ditebang. }\end{array}$ & $\begin{array}{l}\text { Teknis pelaksanaan rehabilitasi } \\
\text { dan reforestasi lebih jelas } \\
\text { karena mengacu pada hasil } \\
\text { inventarisasi hutan. Penebangan } \\
\text { selektif dengan penanaman } \\
\text { kembali (sistem TPTI); } \\
\text { atau sistem Tebang Habis } \\
\text { dengan regenerasi buatan. } \\
\text { Pilihan sistem yang diambil } \\
\text { harus menyertakan rencana } \\
\text { pengelolaan hutan lindung. }\end{array}$ \\
\hline $\begin{array}{l}\text { Pajak yang } \\
\text { dibayarkan }\end{array}$ & DR dan PSDH. & DR dan PSDH. & $\begin{array}{l}\text { Menetapkan tenggat pajak dan } \\
\text { retribusi kehutanan. }\end{array}$ \\
\hline
\end{tabular}


pelaksanaannya (SK Dirjen) membebankan tanggung jawab ini kepada Kepala Dinas Kehutanan Kabupaten, dengan persetujuan dari Gubernur. Pada kenyataannya, Pemerintah Provinsi dan Kabupaten cenderung memilih dan memilah sendiri kebijakan mana yang akan mereka ikuti atau yang lebih menguntungkan bagi mereka. Di Papua, Pemerintah Provinsi telah merancang perundangan yang memberikan kewenangan kepada Gubernur untuk mengeluarkan perizinan pemungutan hasil hutan kayu berbasis masyarakat.

Contoh lainnya adalah ketika Kepmen hanya merujuk pada kegiatan-kegiatan pemungutan non komersial, SK Dirjen sebagai keputusan pelaksanaannya malah cenderung merujuk pada kegiatan-kegiatan pemungutan hasil hutan untuk tujuan komersial. Padahal kebijakan-kebijakan tersebut menjelaskan bahwa kegiatan pemungutan hasil hutan oleh masyarakat adat diperbolehkan untuk jangka waktu yang tidak ditentukan dan mencakup daerah yang juga tidak disebutkan luasan maksimumnya. Hal ini mengakibatkan terdapat perbedaan alokasi luas wilayah dan kerangka waktu masa berlaku izin pemungutan hasil hutan antara perizinan yang dikeluarkan oleh Pemerintah Provinsi dengan pemerintah-pemerintah kabupaten di Papua.

Sejak desentralisasi berlangsung di kabupaten Manokwari, sedikitnya ada tiga cara bagi masyarakat adat untuk memperoleh akses terhadap sumberdaya hutan. Pertama, mereka dapat berunding dengan pemilik konsesi HPH untuk memperoleh kompensasi finansial; Kedua, mereka dapat mengajukan permohonan kepada Pemerintah Kabupaten untuk mendapatkan IHPHA (Izin Hak Pengelolaan Hutan Adat); Ketiga, mereka dapat mengajukan permohonan pada Pemerintah Provinsi untuk mendapatkan IPKMA (Izin Pemanfaatan Kayu oleh Masyarakat Adat). Sejalan dengan peraturan perundangan nasional, Pemerintah Provinsi dapat mengeluarkan IPK-MA kepada perorangan, perusahaan swasta yang bermitra dengan masyarakat adat, organisasi masyarakat adat seperti Lembaga Masyarakat Hukum Adat (LMHA), atau koperasi masyarakat (Kopermas). Namun dalam prakteknya, Pemerintah Provinsi Papua hanya mengeluarkan perizinan bagi masyarakat yang secara resmi membentuk lembaga ekonomi masyarakat atau koperasi yang dikenal sebagai 'Kopermas'. Tabel 1 menyajikan secara lengkap analisis kebijakan sektor kehutanan, khususnya yang terkait dengan akses masyarakat terhadap pengambilan keputusan dan perolehan manfaat dari hasil hutan di era desentralisasi. Beberapa hal penting dari hasil analisa tersebut antara lain sebagai berikut:

1. Seiring berjalannya Otonomi khusus di Papua, selain konsesi-konsesi HPH skala besar yang ada masih terus beroperasi, Pemerintah Pusat juga masih mengeluarkan perizinan $\mathrm{HPH}$ baru di provinsi tersebut. Dengan kewenangan barunya, Pemerintah provinsi menyikapi hal tersebut dengan mengeluarkan kebijakan ${ }^{7}$ yang mewajibkan pemilik konsesi HPH untuk memberikan ganti rugi atas kayu yang mereka peroleh dari hutan kepada masyarakat pemilik hak ulayat.

2. Sejak tahun 2002, masyarakat lokal memiliki akses lebih besar terhadap pemanfaatan hasil hutan dengan mengajukan permohonan pada pemerintah provinsi ${ }^{8}$ untuk memperoleh IPK-MA. Perizinan ini meliputi daerah seluas 250-1.000 ha yang berlaku selama satu tahun.

3. Pada bulan April 2004, Pemerintah Kabupaten Manokwari mengeluarkan IHPHA yang memberikan kesempatan pada Kopermas untuk mengelola hutan seluas 2.000 ha, dalam kurun waktu dua puluh tahun'.

Kebijakan kabupaten yang baru ini menetapkan bahwa hanya Kopermas yang berhak memperoleh perizinan IHPHA. Secara singkat, kebijakan tersebut menjelaskan peran dan kewajiban jangka panjang bagi investor dalam pengembangan SDM lokal (seperti pelatihan, pengembangan aktivitas pemanfaatan kayu oleh masyarakat); pembangunan infrastruktur setempat; serta mekanisme kerjasama antara Kopermas dengan mitra kerja (investor). Misalnya, dalam kebijakan ini ditegaskan bahwa mitra kerja Kopermas harus berdomisili di Manokwari dan telah menjalankan usahanya secara terus menerus selama sekurang-kurangnya tiga tahun. Masyarakat juga dapat berpartisipasi dalam pengambilan keputusan karena perijinan yang diberikan pada Kopermas juga harus disetujui oleh Lurah atau Camat, dengan sepengetahuan masyarakat setempat. Untuk menjamin kelayakan dan ketersediaan lahan yang memadai untuk IHPHA dan juga untuk menjamin masyarakat setempat dapat memperoleh manfaat dari sistem baru ini, Pemerintah Kabupaten Manokwari mewajibkan pemilik konsesi HPH untuk mengalokasikan seluas-luasnya 10.000 ha dari areal konsesi mereka untuk masyarakat adat yang mengajukan izin IHPHA ${ }^{10}$.

Dengan membandingkan analisis terhadap kebijakankebijakan di tingkat nasional, provinsi, dan kabupaten tentang sistem perizinan pemanfaatan hutan oleh masyarakat adat tersebut terbentuk gambaran bahwa Pemerintah Kabupaten Manokwari cukup memiliki komitmen kuat untuk memperbaiki penghidupan masyarakatnya; mendukung konservasi dan pengelolaan hutan yang berkelanjutan; serta mempertahankan sumber-sumber alam setempat dari oknum investor atau mitra kerja Kopermas yang tidak bertanggung jawab.

\section{Perubahan Paradigma dalam \\ Pengelolaan Hutan di Papua}

Dalam masa Orde Baru, kebijakan Pemerintah Pusat terhadap HPH skala besar adalah menyarankan dilakukannya program Pembinaan Masyarakat Desa Hutan $\left(\mathrm{PMDH}^{11}\right)$. Dalam kenyataannya, di Papuaseperti kebanyakan kabupaten di seluruh Indonesiamasyarakat setempat menerima sangat sedikit keuntungan dari hasil hutan maupun dari program PMDH tersebut. 
Analisis kami menunjukkan bahwa dalam era desentralisasi penyerahan kewenangan kepada tingkat otoritas yang lebih rendah sangat berpengaruh pada peningkatan akses masyarakat atas keuntungankeuntungan finansial jangka pendek. Pada beberapa kasus, keterbukaan di era desentralisasi juga memperbaiki akses masyarakat pada pengambilan keputusan, setidaknya yang berhubungan dengan pemungutan hasil-hasil hutan di daerah mereka sendiri. Tabel 2 menggambarkan perbandingan dari akses masyarakat lokal terhadap manfaat yang diperoleh dari hutan dan dalam pengambilan keputusan sebelum dan sesudah desentralisasi.

Kesempatan masyarakat lokal untuk dapat berperan dalam pembangunan jangka panjang sektor kehutanan di Manokawari terhambat oleh beberapa faktor seperti: kekurangan modal, keahlian dan teknologi untuk mengelola sumberdaya hutan mereka secara mandiri. Masyarakat lokal belum cukup memiliki kemampuan bernegosiasi dengan mitra kerja, apalagi jika harus berhubungan dengan perusahaan-perusahaan kayu yang lebih berpengalaman. Dari hasil pengamatan di lapangan terbukti bahwa sebagian investor memanfaatkan beberapa kelompok masyarakat lokal untuk keuntungan mereka sendiri. Namun demikian, pada sebagian kelompok masyarakat lain juga ada yang berhasil membuat perjanjian-perjanjian yang lebih seimbang dengan investor melalui sistem Kopermas. Perjanjian tersebut pada umumnya mengatur hal-hal yang berhubungan dengan perolehan keuntungan dari pemanfaatan hutan seperti: uang ketuk pintu; pembagian keuntungan per meter kubik dari produksi kayu; pembangunan infrastruktur lokal dan kegiatan penanaman hutan adat pasca penebangan; dan berbagai bentuk ganti rugi pemanfaatan lahan. Kesepakatan akhir bisa sangat berbeda antar satu Kopermas dengan yang lainnya. Sebagai contoh, uang ketuk pintu yang harus dibayarkan pada masyarakat adat pemilik ulayat di Manokwari berkisar antar Rp 10-60 juta untuk setiap konsesi seluas 1.000 ha.

Selain itu, setiap Kopermas juga memiliki ketentuan dan cara tersendiri dalam mendistribusikan keuntungan yang diperoleh dari kerjasama dengan investor tersebut diantara para anggotanya. Pada beberapa Kopermas, selain dalam bentuk uang, hasil keuntungan juga dipergunakan untuk investasi proyek-proyek jangka panjang seperti jembatan, jalan, perumahan, sarana angkutan masyarakat, pendidikan ataupun pelatihan.

Secara umum keuntungan finansial yang diperoleh masyarakat melalui kemitraan dengan pemilik konsesi $\mathrm{HPH}$ lebih kecil daripada dengan investor non-HPH. Sebagai contoh, pemilik konsesi HPH membayar paling tinggi Rp. $50.000 / \mathrm{m}^{3}$, sementara investor non-HPH bersedia membayar sampai Rp. 200.000/ $\mathrm{m}^{3}$ untuk jenis kayu yang sama. Pemilik konsesi HPH beralasan bahwa mereka telah memberikan berbagai manfaat tidak langsung bagi masyarakat lokal dengan membangun infrastruktur jalan dan tempat penampungan kayu tebangan, yang juga dapat digunakan bebas oleh Kopermas dan investor non-HPH.

Dari hasil kerjasama dengan mitra kerja, beberapa anggota masyarakat perorangan juga dipekerjakan dalam kegiatan pemungutan hasil hutan. Namun, kurangnya pengalaman dalam usaha kehutanan

Tabel 2. Perbandingan akses atas keuntungan dan pengambilan keputusan

\begin{tabular}{|c|c|c|c|c|}
\hline \multirow[t]{2}{*}{ Kategori } & \multirow{2}{*}{$\begin{array}{l}\text { Ijin HPH Pra } \\
\text { Desentralisasi }\end{array}$} & \multicolumn{3}{|c|}{ Ijin Pemanfaatan Hutan di Era Desentralisasi } \\
\hline & & $\mathrm{HPH}$ & IPK-MA & IHPHA \\
\hline Pemilik ijin & $\begin{array}{l}\text { Perusahaan } \\
\text { swasta. }\end{array}$ & $\begin{array}{l}\text { Perusahaan } \\
\text { swasta. }\end{array}$ & Kopermas. & Kopermas. \\
\hline $\begin{array}{l}\text { Kegiatan } \\
\text { Pemungutan } \\
\text { kayu }\end{array}$ & $\begin{array}{l}\text { Oleh pemilik } \\
\text { konsesi. }\end{array}$ & $\begin{array}{l}\text { Oleh pemilik } \\
\text { konsesi, tapi } \\
\text { ditekankan untuk } \\
\text { dapat bermitra } \\
\text { dengan Kopermas. }\end{array}$ & $\begin{array}{l}\text { Oleh mitra kerja } \\
\text { atau oleh Kopermas. }\end{array}$ & $\begin{array}{l}\text { Oleh mitra kerja atau } \\
\text { oleh Kopermas. }\end{array}$ \\
\hline $\begin{array}{l}\text { Keuntungan } \\
\text { yang diperoleh } \\
\text { masyarakat adat }\end{array}$ & $\begin{array}{l}\text { Program } \\
\text { Pembinaan } \\
\text { Masyarakat } \\
\text { Desa Hutan } \\
(\text { PMDH). }\end{array}$ & $\begin{array}{l}\text { Program PMDH, } \\
\text { ‘uang ketuk } \\
\text { pintu’ dan ganti } \\
\text { rugi pemanfaatan } \\
\text { lahan. }\end{array}$ & $\begin{array}{l}\text { 'Uang ketuk pintu’, } \\
\text { bagi hasil produksi } \\
\text { kayu, dan ganti rugi } \\
\text { pemanfaatan lahan. }\end{array}$ & $\begin{array}{l}\text { Selain pembagian } \\
\text { keuntungan, dan ganti } \\
\text { rugi pemanfaatan } \\
\text { lahan, masyarakat juga } \\
\text { mendapat beragam } \\
\text { keuntungan yang lebih } \\
\text { luas dan kesempatan } \\
\text { bernegosiasi dengan mitra } \\
\text { kerja. }\end{array}$ \\
\hline $\begin{array}{l}\text { Pengambil } \\
\text { Keputusan }\end{array}$ & $\begin{array}{l}\text { Pemerintah } \\
\text { pusat. }\end{array}$ & $\begin{array}{l}\text { Pemerintah pusat } \\
\text { dan provinsi, } \\
\text { pemilik HPH, } \\
\text { perwakilan } \\
\text { masyarakat lokal. }\end{array}$ & $\begin{array}{l}\text { Pemerintah provinsi, } \\
\text { masyarakat lokal, } \\
\text { Kopermas, dan mitra } \\
\text { kerja. }\end{array}$ & $\begin{array}{l}\text { Pemerintah kabupaten, } \\
\text { masyarakat adat, } \\
\text { Kopermas, dan mitra } \\
\text { kerja. }\end{array}$ \\
\hline
\end{tabular}



yang timbul di tingkat kabupaten dapat dibicarakan bersama secara berkala dalam pertemuan tersebut.

- Mengembangkan sistem silvikultur yang sesuai untuk pemungutan hasil hutan oleh masyarakat hukum adat, dengan mempertimbangkan kemampuan masyarakat lokal, ketergantungan terhadap sumberdaya, dan nilai-nilai budaya. Hal ini akan sangat membantu untuk menjamin kelestarian produksi dan kelestarian fungsifungsi hutan di masa mendatang.

\section{Catatan akhir}

1 Hak bersama yang dipunyai masyarakat hukum adat atas suatu wilayah adat tertentu untuk mengambil manfaat dari sumber daya yang ada dalam wilayah tersebut.

2 UU No. 21/2001 Bab XI Pasal 43.

3 No. 310/kpts-II/1999 tentang Pedoman Pemberian Hak Pemungutan Hasil Hutan dan No. 317/Kpts-II/1999 tentang Hak Pemungutan Hasil Hutan Masyarakat Hukum Adat pada Areal Hutan Produksi.
${ }^{4}$ Sistem HPHH dinyatakan tidak berlaku dengan keluarnya SK Menteri No. 6886/kpts-II/2002 tentang Pedoman dan Tata Cara Pemberian Ijin Pemungutan Hasil Hutan (IPHH) pada Hutan Produksi.

5 Keputusan Pelaksanaan Direktur Jenderal Pemanfaatan Hutan No. 199/Kpts/VI-Set/1999.

6 Sistem Kopermas diatur berdasarkan Surat Keputusan Bersama Menteri Kehutanan dan Perkebunan dan Menteri Koperasi dan Usaha Kecil dan Menengah No. 234/kptsIV/1999 dan No.01/skb/M/IV/1999, tentang Pendayagunaan Koperasi dalam Sektor Kehutanan dan Perkebunan dan sebuat SK Menteri Koperasi dan Usaha Kecil dan Menengah No. 107/bh/KDK/238/XI/2000 tentang Pengesahan Koperasi Masyarakat (Kopermas).

7 SK Gubernur No. 50/2001 tentang Standar Pemberian Kompensasi bagi Masyarakat Adat untuk Kayu yang diambil dari Wilayah Ulayat.

${ }^{8}$ SK Gubernur No. 522.2/3386/SET/2002 tentang Penetapan Hak-hak Masyarakat Adat untuk Pemungutan Hasil Hutan.

${ }^{9}$ SK Bupati No. 274/2004 tentang Ijin Hak Pengelolaan Hutan Adat (IHPHA).

${ }^{10}$ SK Bupati Manokwari No. 274/2004 Bab VI, Pasal 14.

11 Alokasi dana untuk PMDH, menurut SK Menteri Kehutanan dan Perkebunan No. 610/Kpts-II/1993 adalah Rp. 1.000/m³. 
Max J. Tokede dan Yosias Gandhi dari Universitas Papua; Dede Wiliam dan Siân McGrath dari CIFOR menulis Ringkasan Desentralisasi ini dari laporan yang berjudul: 'Dampak Otonomi Khusus di Sektor Kehutanan Papua: Pemberdayaan Masyarakat Hukum Adat dalam Pengusahaan Hutan di Kabupaten Manokwari. Karya tulis ini didanai oleh ACIAR dan DFID dalam proyek: Dapatkah desentralisasi memberikan manfaat bagi hutan dan masyarakat miskin? Pendapat yang dinyatakan dalam tulisan ini adalah milik penulis pribadi dan tidak selalu mencerminkan pandangan badan penyandang dana.
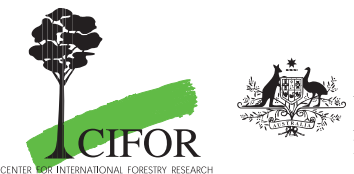

Australian Government

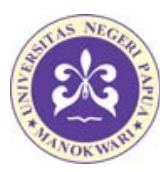

Center for International Forestry Research, CIFOR 